\title{
Multifocal Pseudotumorous Form of Neuroparacoccidioidomycosis in an Immunocompetent Patient: A Clinicopathological Review Based on a Case Report
}

\section{Neuroparacoccidioidomicose multifocal de forma pseudotumoral em paciente imunocompetente: Uma revisão clinicopatológica baseada em um relato de caso}

Eduardo Cambruzzi ${ }^{1,2,3,4,5(1) ~ K a r l a ~ L a i s ~ P e ̂ g a s ~}{ }^{2,3}$ Gabriella Bezerra Cortês Nascimento ${ }^{6(1)}$ José Nathan Andrade Muller da Silva6(i) Natália Brandelli Zandoná6(i) William Pegoraro Kus6(0) Felipe Lourezon Schiavo ${ }^{70}$ Samir Cezimbra dos Santos ${ }^{70}$

${ }^{1}$ Department of Pathology, Universidade Federal do Rio Grande do Sul, Porto Alegre, RS, Brazil

2 Department of Pathology, Hospital Santa Rita, Complexo Hospitalar Santa Casa, Porto Alegre, RS, Brazil

${ }^{3}$ Department of Pathology, Grupo Hospitalar Conceição, Porto Alegre, RS, Brazil

${ }^{4}$ Department of Pathology, Universidade Luterana do Brasil, Canoas, RS, Brazil

${ }^{5}$ Department of Pathology, Instituto de Cardiologia, Fundação

Universitária de Cardiologia, Porto Alegre, RS, Brazil

${ }^{6}$ Grupo Hospitalar Conceição, Porto Alegre, RS, Brazil

${ }^{7}$ Department of Neurosurgery, Grupo Hospitalar Conceição, Porto Alegre, RS, Brazil
Address for correspondence Eduardo Cambruzzi, MD, PhD, Departmento de Patologia, Hospital Santa Rita, Complexo Hospitalar Santa Casa, Rua Sarmento Leite, $187,2^{\circ}$ andar, Porto Alegre, RS, Brazil (e-mail: dudacambruzzi@yahoo.com.br).

Arq Bras Neurocir 2021;40(2):e195-e199.
Abstract
Keywords
- paracoccidio- domycosis
- south american blastomycosis
- paracoccidioides brasiliensis
- central nervous system
- mycosis
- pathology

Neuroparacoccidiodimycosis (NPDM) is an uncommon granulomatous disease, which more frequently affects immunocompromised male patients over 30 years of age in the course of chronic lung disease. Paracoccidioides brasiliensis (PB) is an endemic fungus in Brazil, and grows as thick-walled yeast (with round to oval bodies) measuring $10 \mu \mathrm{m}$ to $60 \mu \mathrm{m}$ in diameter. Neuroparacoccidiodimycosi may develop many years after transmission and/or primary lung involvement. The authors describe a case of NPDM affecting a male patient, 52 years of age, farmer, heavy smoker, with clinical complaint of headache, asthenia, seizures, and prostration in the previous nine months. Upon physical examination, the patient presented regular general condition, without other relevant physical alterations. Computed tomography (CT) showed multiple bilateral pulmonary nodules associated to enlargement of the mediastinal lymph node. Magnetic resonance imaging (MRI) and CT scans of the central nervous system showed received

January 7, 2020

accepted

August 24, 2020

published online

November 26, 2020
DOI https://doi.org/ 10.1055/s-0040-1719005. ISSN 0103-5355. (c) 2020. Sociedade Brasileira de Neurocirurgia. All rights reserved. This is an open access article published by Thieme under the terms of the Creative Commons Attribution-NonDerivative-NonCommercial-License, permitting copying and reproduction so long as the original work is given appropriate credit. Contents may not be used for commercial purposes, or adapted, remixed, transformed or built upon. (https://creativecommons.org/ licenses/by-nc-nd/4.0/)

Thieme Revinter Publicações Ltda., Rua do Matoso 170, Rio de Janeiro, RJ, CEP 20270-135, Brazil 


\section{Resumo}

\author{
Palavras-chave \\ - paracoccidio- \\ domicose \\ - blastomicose da \\ América do Sul \\ - paracoccidioides \\ brasiliensis \\ - sistema nervoso \\ Central \\ - Micose \\ - patologia
}

six heterogeneous nodular lesions compromising the frontal and parietal lobes, the largest one measuring $3.8 \times 3.2 \times 3.2 \mathrm{~cm}$. The hypothesis of a neoplastic process compromising the lung and brain was considered. A biopsy of the mediastinal lymph node showed epithelioid granulomas, which exhibited round, thin-walled fungal structures in Grocott silver stain. The stereotactic biopsy of the frontal lesion was constituted by necrotic tissue admixed with some round to oval, thin-walled fungi measuring $10 \mu \mathrm{m}$ to $60 \mu \mathrm{m}$, compatible with PB (identified on Grocott silver stain/confirmed in culture). The diagnosis of NPDM was then established. The employed therapeutic regimen was intravenous amphotericin B, itraconazole, and sulfamethoxazole-trimetropin. After ninety days of clinical follow-up, no episodes of seizures/neurological deficits were identified, and a marked decrease in the number and size of the lung and brain lesions were found.

A neuroparacoccidiodimicose (NPDM) é uma doença granulomatosa incomum, que acomete mais freqüentemente pacientes imunocomprometidos do sexo masculino com mais de 30 anos, no curso de doença pulmonar crônica. Paracoccidioides brasiliensis ( $\mathrm{PB}$ ) é um fungo endêmico no Brasil e cresce como levedura de parede espessa (com corpos arredondados a ovais) medindo 10-60 $\mu \mathrm{m}$ de diâmetro. A NPDM pode se desenvolver muitos anos após a transmissão e / ou envolvimento pulmonar primário. Os autores descrevem um caso de NPDM em paciente masculino, 52 anos, agricultor, tabagista pesado, com queixa clínica de cefaleia, astenia, convulsões e prostração nos últimos nove meses. Ao exame físico, o paciente apresentava estado geral regular, sem outras alterações físicas relevantes. A tomografia computadorizada (TC) mostrou múltiplos nódulos pulmonares bilaterais associados a linfonodomegalia mediastinal. A TC / ressonância magnética do sistema nervoso central revelou seis lesões nodulares heterogêneas comprometendo os lobos frontal e parietal, a maior delas medindo $3,8 \times 3,2 \times 3,2 \mathrm{~cm}$. Foi considerada a hipótese do processo neoplásico comprometendo pulmão e cérebro. A biópsia de linfonodo mediastinal mostrou granulomas epitelioides, que exibiam estruturas fúngicas arredondadas e de paredes finas na coloração pela prata de Grocott. A biópsia estereotáxica da lesão frontal era constituída por tecido necrótico entremeado por algumas estruturas fúngicas redondas a ovais e de parede fina, medindo 10-60 $\mu \mathrm{m}$, compatível com PB (identificado na coloração de prata Grocott / confirmado em cultura). O diagnóstico de NPDM foi então estabelecido. O esquema terapêutico empregado foi anfotericina B intravenosa, itraconazol e sulfametoxazol-trimetropina. Após 90 dias de acompanhamento clínico, nenhum episódio de convulsão / déficit neurológico foi identificado, e uma diminuição acentuada no número e tamanho das lesões pulmonares e cerebrais foi encontrada.

\section{Introduction}

Central nervous system (CNS) mycoses have assumed greater importance as the number of immunocompromised patients has increased over the past few decades. ${ }^{1-3}$ Fungal infections in the CNS have also been increasing, because of the growing use of complex surgical procedures, invasive medical devices, and long-term broad-spectrum antibiotics. Considerable progress has been made in our understanding of fungal pathobiology, in special due to the sequencing of fungal genomes and the employment of animal models to determine the different components of fungal virulence. ${ }^{1-3}$ The epidemiology of CNS fungal disease is variable in the literature. Relevant epidemiological data come from the databse of the Transplant-Associated Infection Surveillance Network. ${ }^{4}$ Many CNS mycoses are preceded by lung infections, and fungi reach the CNS via the hematogenous route. The risk factors that lower host resistance include neutropenia, hematological malignancy, steroids, diabetes mellitus, systemic lupus, renal failure, and impaired cell-mediated immunity. ${ }^{1,2,4}$

Paracoccidiodomycosis (PDM), or South American blastomycosis, is caused by Paracoccidioides brasiliensis (PB). The fungi grow as thick-walled yeast with round to oval bodies, which are $10 \mu \mathrm{m}$ to $20 \mu \mathrm{m}$ in diameter and give rise to single or 
multiple thin-necked buds. ${ }^{1,5,6}$ These fungi probably live in the vegetation or soil. Usually, PDM is a granulomatous disease that initially compromises the lungs and the oral mucosa, and then spreads to the lymph nodes, the adrenal glands, and, rarely, to the CNS. ${ }^{1,3,5,6}$ Herein, the authors present a case of neuroparacoccidioidomycosis (NPDM) affecting an immunocompetent male patient, and discuss the pathological and clinical data of this uncommon cerebral mycosis.

\section{Case Report}

A male patient, 52 years of age, farmer, heavy smoker for 30 years, was referred to the hospital service with a clinical complaint of headache, asthenia, fatigue, and prostration in the previous nine months. Upon physical examination, the patient presented a regular general condition, without other relevant physical alterations. The patient's previous history did not present significant pathological processes. A conventional chest radiological study revealed a micronodular interstitial infiltrate in both lungs. A computed tomography (CT) scan of the chest showed multiple bilateral and coalescent pulmonary nodules associated to enlargement of the mediastinal lymph node (-Fig. 1). The patient evolved with episodes of seizures. The hypothesis of a neoplastic process compromising the lung and brain was considered. Magnetic resonance imaging (MRI) and CT scans of the CNS showed 6 heterogeneous nodular lesions, which compromised predominantly the white matter of the frontal and parietal lobes bilaterally, with surrounding areas of edema and narrowing zones of the brain grooves, and the largest one measured $3.8 \times 3.2 \times 3.2 \mathrm{~cm}$ (-Fig. 2). The lesions were hypointense at $\mathrm{T} 2$, with a slight peripheral signal at $\mathrm{T} 1$ and diffusion restriction. On the CT/MRI scans of the abdomen, no significant alterations were observed. The patient had negative serology for HIV, hepatitis B and C, syphilis and toxoplasmosis. An analysis of the cerebrospinal fluid (CSF) did not reveal any significant data. In a biopsy of the mediastinal lymph node, we identified anthracosis and the formation of epithelioid granulomas, which exhibited small, round, thin-walled fungal structures in Grocott silver stain. A stereotactic biopsy of the frontal

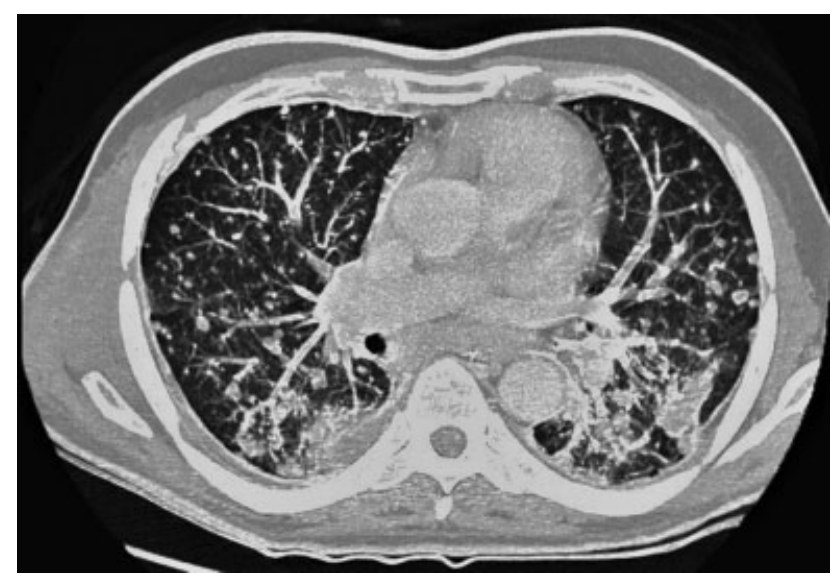

Fig. 1 Lung paracoccidioidomycosis: computed tomography scan exhibiting multiple bilateral and coalescent pulmonary nodules.

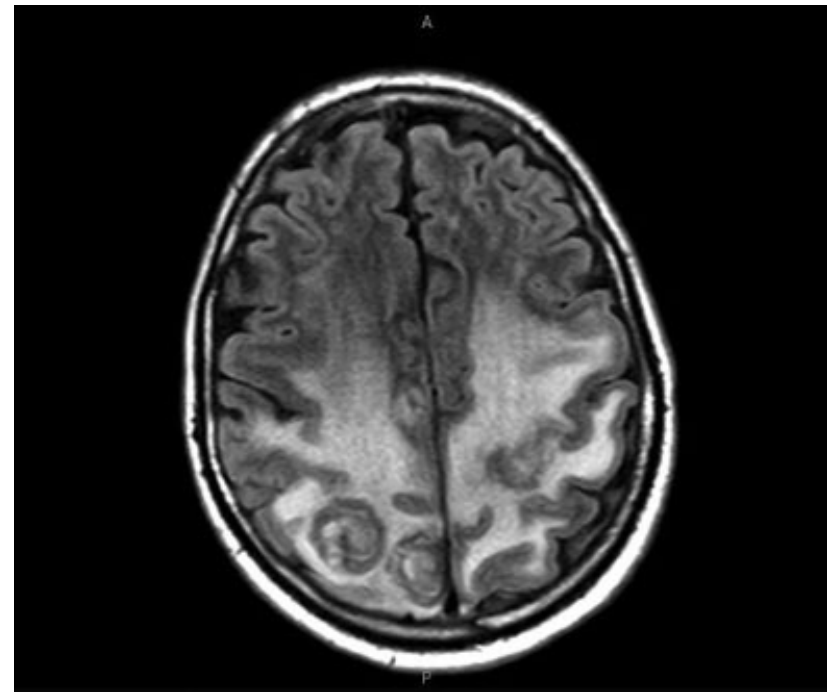

Fig. 2 Neuroparacoccidioidomycosis: magnetic resonance imaging (axial - fluid attenuated inversion recovery [FLAIR] image) scan showing two heterogeneous nodular lesions compromising the parietal lobes, with surrounding areas of edema.

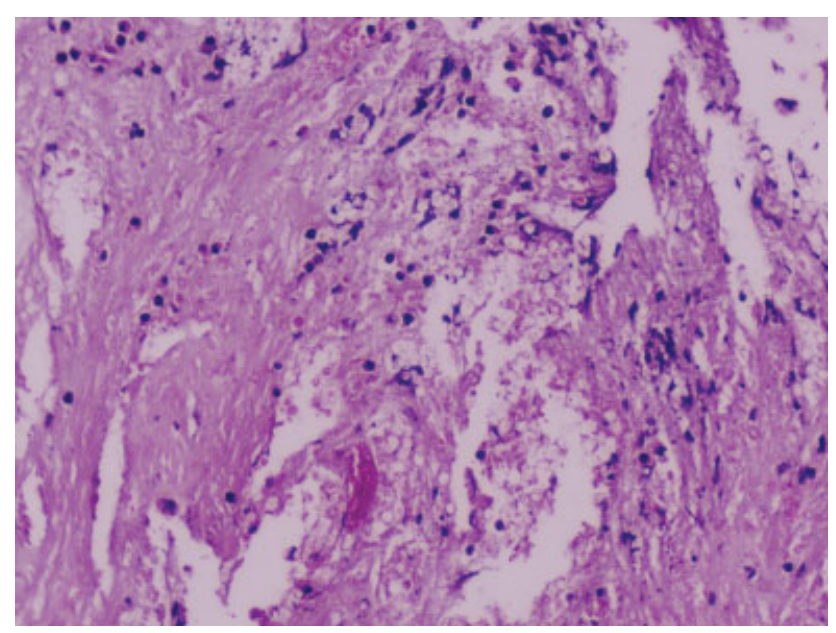

Fig. 3 Central nervous system paracoccidioidomycosis: necrotic tissue obtained by stereotactic biopsy, hematoxylin-eosin, 100X.

lesion was constituted by an amorphous, eosinophilic necrotic tissue (hematoxylin-eosin technique; - Fig. 3) admixed by some round to oval, thin-walled fungal structures measuring $10 \mu \mathrm{m}$ to $60 \mu \mathrm{m}$, compatible with PB (identified on Grocott silver stain and confirmed in culture; - Fig. 4). The diagnosis of pulmonary PDM determining secondary involvement of the CNS was then established. The proposed therapeutic regimen was the use of intravenous amphotericin B, itraconazole, and sulfamethoxazole-trimetropin. In the first week of the pharmacological treatment, the patient developed respiratory failure, hypokalemia, and hypomagnesemia, and mechanical ventilation was started. Thirty days after this episode, the patient showed an improvement in his general clinical condition. After ninety days of clinical follow-up, no episodes of seizures or neurological deficits were identified, and a marked decrease in the number and size of the lung and brain lesions was observed. 


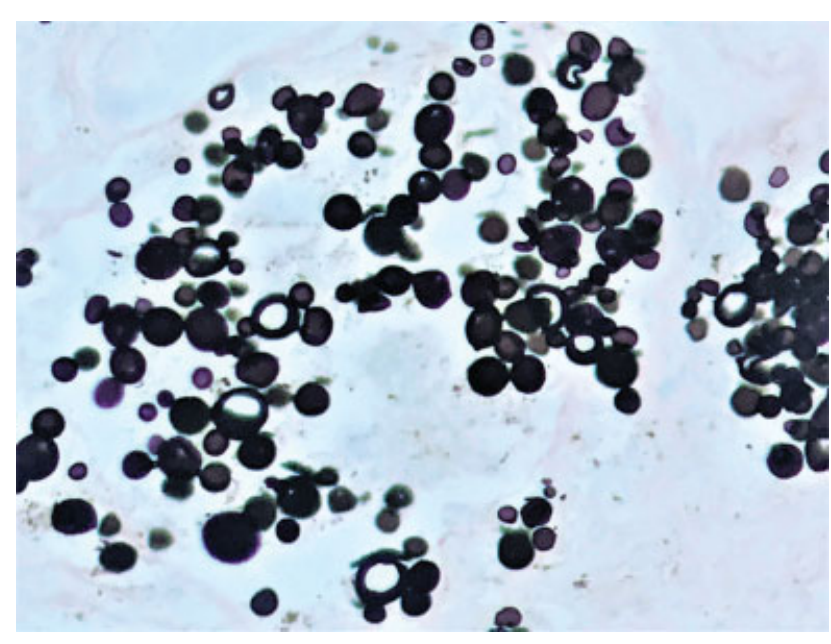

Fig. 4 Central nervous system paracoccidioidomycosis: thick-walled yeasts with round to oval bodies identified in Grocott methenamine silver stain, $200 \mathrm{X}$.

\section{Discussion}

First described by Lutz in 1908, PDM is very restricted to geographic areas such as Central and South America. In Brazil, PDM is an endemic disease. ${ }^{1,7-9}$ Most compromised patients are over 30 years of age, and males are more frequently affected. The lungs are primarily involved, and symptoms of PDM often develop many years after transmission. ${ }^{1,7-9}$ This long latent period may be due to the fungus lying dormant in the lymph nodes. The severity of the disease is related to host immunity. Most patients present with various combinations of fever, cough, night sweats, weight loss, or chills. Pulmonary findings may be localized or may be part of a more disseminated disease. ${ }^{7-11} \mathrm{~A}$ small number of patients remain subclinical. Acute lung infection rapidly spreads to the lymph nodes, liver and spleen. Radiological findings are unspecific, and include micronodular infiltrates, foci of consolidation, cavities, fibrosis or, infrequently, calcified nodules. ${ }^{7-11}$ The histopathological findings range from neutrophilic microabscesses, scattered interstitial necrotizing granulomas, and consolidative granulomatous pneumonia. Progressive pulmonary disease is more common than acute/subacute lung involvement. ${ }^{2,3,5,8,12}$ It compromises older patients who probably develop reactivation many years after transmission. Chests radiographs exhibit confluent/patchy nodular infiltrates in the mid/basal segments, usually bilateral and symmetrical. The pathological findings include lung scarring with a coarse, hobnail appearance, cavities, ulceration of the large airways, bronchiectasis, dense fibrous pleural adhesions, and pleural effusions. , $3,5,8,12$ Lung PDM can resemble and coexist with blastomycosis and tuberculosis, and a mixed piogenic and granulomatous inflammatory response is typical of the disease. Numerous organisms are usually present within giant cells. $^{2-4,6,8,9}$

Dissemination from a primary lung disease may involve regional lymph nodes and eventually the CNS, which is usually related to the chronic form of the pulmonary disease and male patients after the third decade of life who live in rural areas. The prevalence of NPDM ranges from $4 \%$ to $15 \%$ of cases of systemic PDM. ${ }^{1,4,10,12,13}$ Manifestations of the involvement of the CNS include headache, lethargy, raised intracranial pressure, and personality changes. Neuroparacoccidioidomycosis is most commonly associated with symptoms and signs of an expansive lesion in the brain (pseudotumorous form) or to a meningitic form. $2,3,5,8,9,12,14$ On gross, the most common form of NPDM is the pseudotumorous form, which usually exhibits well-circumscribed necrotic nodules measuring from a few millimeters to several centimeters in diameter. Supratentorial lesions are predominantly found in NPDM (around 70\% of the cases), and the frontal and parietal lobes are the most common locations. ${ }^{2,3,5,8,9,12,14}$ Spinal PDM accounts for $0.6 \%$ of all cases of systemic PDM, and for $4 \%$ of the cases of NPDM. ${ }^{4,5,10}$ The leptomeningitic form is granulomatous, predominantly basal, and may cause hydrocephalus. When it affects the dura mater, NPDM may resemble meningiomas. On microscopy, paracoccidiodomycomas (pseudotumorous form) exhibit granulomas composed of epithelioid macrophages, Langhans giant cells, necrotic central areas, and lymphocytes. ${ }^{2,5,8,12,13,15}$ A chronic inflammatory infiltrate can be identified in the leptomeninges, and this infiltrate can extend along the Virchow-Robin space into the underlying brain tissue, especially in the hypothalamus. $2,5,8,12,13,15$

A dimorphic fungus, PB forms oval to rounds yeasts with multiple buds at $37^{\circ} \mathrm{C}$ in tissues and in cultures. The fungus is a white mold composed of thin septate hyphae that produce chlamydoconidia, and, when cultured, it produces $<5 \mu \mathrm{m}$ asexual propagules known as microconidia (probably the infectious particle). ${ }^{1,2,7,9,14,16}$ In tissue sections, the organisms are round to oval and $10 \mu \mathrm{m}$ to $60 \mu \mathrm{m}$ in diameter, and have thin, refractive walls. In the hematoxilin-eosin technique, their contents may be basophilic or amphophilic. ${ }^{1,2,7,9,14}$ P. brasiliensis reproduces by multiple buds, which can be roughly equal or may vary in size and are linked to the parent by narrow beds. In fibrous longstanding granulomatous lesions, the yeasts may be fragmented, distorted and unevenly stained by fungal stains. Rarely, hyphae are formed in the tissues. ${ }^{3,5,12,13,16}$ Diagnosis of lung disease can be established by sputum, bronchioalveolar lavage, and biopsies. If the submitted material is warmed with $5 \%$ potassium hydroxide ( $\mathrm{KOH})$, the yeasts are doubly refractive. Cell-block preparations and histological slides stained with Grocott silver stain are also sensitive techniques. In cultures, mold colonies can be obtained after incubation in Sabouraud dextrose agar supplemented with cycloheximide. ${ }^{3,5,12,13}$ Serological tests are also useful for the presumptive diagnosis of NPDM, and these tests can be used to monitor the response to the treatment too. ${ }^{2,12,13,16-19}$ The CSF analysis has both low sensitivity and low specificity. Gp43 and gp70 $\mathrm{PB}$ antigens in body fluids and in the CSF (inh-enzyme-linked immunosorbent assay [ELISA] method) can be helpful for the diagnosis of the disease. The ELISA anti-gp 43 has $89 \%$ of sensitivity and $10 \%$ of specificity. ${ }^{12,13,16-19}$ The CT/MRI scans exhibit an expansive, ring-enhancement lesion, with surrounding edema, in the pseudotumorous form of NPDM. On MRI, the pseudotumorous form can appear as hyper-, iso-, or hypointense lesions on $\mathrm{T} 1$ and $\mathrm{T} 2$-wieghted imaging. 
Diffusion-weighted imaging does not normally demonstrate signal restriction. ${ }^{2,5,6,13,21}$ In the present case, the authors report an immunocompetent, heavy smoker farmer, who developed the classic pseudotumorous form of NPDM in the course of concomitant chronic lung disease. The initiallyadmitted clinical hypothesis was primary lung neoplasia with secondary implants in the brain parenchyma, due previous history of smoking and the radiological data. The identification of fungal structures in the mediastinal lymph nodes and brain biopsies was fundamental to stablish the final diagnosis and correct clinical management.

Differential diagnosis includes Coccidioides immitis (sporangia measuring $30 \mu \mathrm{m}$ to $60 \mu \mathrm{m}$ and containing $1 \mu \mathrm{m}$ to $5 \mu \mathrm{m}$ sporangiospores - it usually occurs as meningitis), Histoplasma capsulatum (a dimorphic, ovoid fungi, measuring $2 \mu \mathrm{m}$ to $5 \mu \mathrm{m}$ ), and Cryptococcus neoformans (yeasts measuring $4 \mu \mathrm{m}$ to $7 \mu \mathrm{m}$ and exhibiting a mucinous capsule). ${ }^{1,2,7,12,13,19,20,22}$ In the presence of the pseudotumorous form of NPDM, the differential diagnosis also includes neoplasms (primary and secondary), abscesses, tuberculosis, and neurocysticercosis. ${ }^{7,12,13,19,20,22-24}$ The therapy includes sulfonamides, amphotericin B and azoles (fluconazole, itraconazole, voriconazole). ${ }^{2,3,8,11,13,14,19}$ Actually, the combination of oral fluconazole and trimethoprim-sulfamethoxazole for long periods (more than 12 months) is also employed in NPDM. 2,3,7,11,13,14,19

\section{Funding}

No funding was received.

\section{Conflict of Interests}

The author have no conflict of interests to declare.

\section{References}

1 de Almeida SM, Salvador GLO, Roza TH, et al. Geographical evaluation of Neuroparacoccidioidomycosis and Paracoccidioidomycosis in Southern Brazil. Mycoses 2018;61(08):587-593

2 Carvalho de Medeiros F, Curcio de Moraes A, Buzelin Nunes M, Dellaretti M. Neuroparacoccidioidomycosis mimicking brain tumor in an immunocompetent patient. Rev Neurol (Paris) 2018; 174(04):268-271

3 Silva-Vergara ML, Rocha IH, Vasconcelos RR, et al. Central nervous system paracoccidioidomycosis in an AIDS patient: case report. Mycopathologia 2014;177(1-2):137-141

4 Kontoyiannis DP, Marr KA, Park BJ, et al. Prospective surveillance for invasive fungal infections in hematopoietic stem cell transplant recipients, 2001-2006: overview of the Transplant-Associated Infection Surveillance Network (TRANSNET) Database. Clin Infect Dis 2010;50(08):1091-1100

5 dos Santos VM, Xavier RM, Cortes JA, Osterne EM, de Worisch Ferreira Lopes M. Pseudotumoral neuroparacoccidioidomycosis: one case report. Mycopathologia 2008;166(03):155-158

6 Reis F, Collier PP, Souza TF, et al. Neuroparacoccidioidomycosis (NPCM): magnetic resonance imaging (MRI) findings. Mycopathologia 2013;175(1-2):181-186
7 Gomes Carvalho Neto E, Coletto A, Biazus PG, Pereira Dos Santos I, Rieder CRM, de Castro Ribeiro M. Neuroparacoccidioidomycosis. Neurol Neuroimmunol Neuroinflamm 2018;6(01):e519

8 de Almeida SM, Roza TH, Salvador GLO, et al. Neurological and multiple organ involvement due to Paracoccidioides brasiliensis and HIV co-infection diagnosed at autopsy. J Neurovirol 2017;23 (06):913-918

9 Fagundes-Pereyra WJ, Carvalho GT, Góes AM, das Chagas Lima e Silva F, de Sousa AA. [Central nervous system paracoccidioidomycosis: analysis of 13 cases]. Arq Neuropsiquiatr 2006;64(2A) 269-276

10 de Almeida SM, Roza TH, Salvador GLO, et al. Autopsy and biopsy study of paracoccidioidomycosis and neuroparacoccidioidomycosis with and without HIV co-infection. Mycoses 2018;61(04): 237-244

11 Francesconi F, da Silva MT, Costa RL, et al. Long-term outcome of neuroparacoccidioidomycosis treatment. Rev Soc Bras Med Trop 2011;44(01):22-25

12 Dall Bello AG, Severo CB, Oliveira FdeM, Severo LC. Disseminated paracoccidioidomycosis (simulating metastatic lung cancer) and Strongyloides stercoralis hyperinfestation in a steroid-treated patient. J Clin Microbiol 2011;49(05):2054-2055

13 Dias AB, Giugno CS, Scapineli JO, Tarso GP, Curtis RM, Lenhardt R. Neuroparacoccidioidomycosis with concomitant pulmonary and vocal cord lesions. Arq Neuropsiquiatr 2018;76(11): 802-804

14 Elias J Jr, dos Santos AC, Carlotti CG Jr, et al. Central nervous system paracoccidioidomycosis: diagnosis and treatment. Surg Neurol 2005;63(Suppl 1):S13-S21, discussion S21

15 Alves GR, Lauda Filho JD, Haygert CJ. Neuroparacoccidioidomycosis. Rev Soc Bras Med Trop 2011;44(05):654

16 de Almeida SM, Queiroz-Telles F, Teive HA, Ribeiro CE, Werneck LC. Central nervous system paracoccidioidomycosis: clinical features and laboratorial findings. J Infect 2004;48(02):193-198

17 Paniago AM, de Oliveira PA, Aguiar ES, et al. Neuroparacoccidioidomycosis: analysis of 13 cases observed in an endemic area in Brazil. Trans R Soc Trop Med Hyg 2007;101(04):414-420

18 Marques da Silva SH, Colombo AL, Blotta MH, Lopes JD, QueirozTelles F, Pires de Camargo Z. Detection of circulating gp43 antigen in serum, cerebrospinal fluid, and bronchoalveolar lavage fluid of patients with paracoccidioidomycosis. J Clin Microbiol 2003;41 (08):3675-3680

19 Jorge LA Jr, Yamashita S, Trindade AP, et al. Pseudotumoral neuroparacoccidioidomycosis of the posterior fossa: A case report and review of the literature. Surg Neurol Int 2017;8:76

20 Rosa Júnior M, Amorim AC, Baldon IV, et al. Paracoccidioidomycosis of the central nervous system: CT and MR imaging findings. AJNR Am J Neuroradiol 2019;40(10):1681-1688

21 Corti M, Trione N, Risso D, et al. Disseminated paracoccidioidomycosis with a single brainstem lesion. A case report and literature review. Neuroradiol J 2010;23(04):454-458

22 Buccheri R, Benard G. Opinion: Paracoccidioidomycosis and HIV immune recovery inflammatory syndrome. Mycopathologia 2018;183(03):495-498

23 de Almeida SM, Roza TH. HIV immune recovery inflammatory syndrome and central nervous system paracoccidioidomycosis. Mycopathologia 2017;182(3-4):393-396

24 Pedroso VS, Vilela MC, Santos PC, Cisalpino PS, Rachid MA, Teixeira AL. Traffic of leukocytes and cytokine up-regulation in the central nervous system in a murine model of neuroparacoccidioidomycosis. Mycopathologia 2013;176(3-4):191-199 